\title{
Journalists' Perception of a Punitive Public: Explaining the Impulse of Social Control
}

\section{Michael McDevitt*}

University of Colorado, Boulder

In a memorable passage, James Carey described journalists evoking "the public" in ritualistic fashion, in language at once celebratory and obeisant:

The god term of journalism-the be-all and end-all, the term without which the enterprise fails to make sense, is the public. Insofar as journalism is grounded, it is grounded in the public ... The public is totem and talisman, and an object of ritual homage [1].

The god of Romans 12 ("Vengeance is mine...") comes to mind for how journalists might imagine the public when media act as an agent of social control. During moral panic, for example, journalists hold deviance accountable to the judgment of the citizenry. In such circumstances, we might say that public opinion "is 'the group' that is 'doing the accepting'” [2].

Reporters and editors are unlikely to acknowledge their contributions to the policing of dissent, of course, but more surprising is the dearth of theorizing on how journalists' perception of the public plays into the social-control impulse. To be sure, perspectives such as the protest paradigm, moral panic, scandals, media ritual, and guarddog journalism have generated insights on representations of deviance and dissent, connecting media sociology with macro perspectives at the level of culture and ideology. Outside the realm of hegemony and social control, scholars have documented journalists' seemingly contradictory attitudes toward readers, depicting reporters as, at once, deferential and dismissive [3]. More recently (2008), Tsfati and Livio examined journalists' perceptions of media influence by way of thirdperson effects [4].

A synthesis of these approaches holds promise for advancing our understanding of why journalists participate in the sanctioning of dissent. My interest in how journalists imagine the public grew from a series of studies on Ward Churchill, an ethic studies scholar who found himself ensnarled in a media frenzy in 2005. Professor Churchill caustically challenged the notion of American innocence following the September 11 attacks. The University of Colorado fired him following charges of research misconduct, but he is best known for his polemic provocations, achieving, in fact, iconic status in reviving the meme of the treasonous professor.

Evidence from interviews with Colorado newspaper journalists, coupled with textual analysis, revealed how reporters imagined a punitive public in response to Churchill's views [5]. The Denver press trafficked in "contextomy" [6], extracting the most inflammatory trope from a Churchill essay, wherein he described some of the World Trade Center victims as "little Eichmanns"[7]. Journalists thereby reified an outraged and anti-intellectual public. Invoking Tuchman [8], we interpreted professional motives as essentially defensive and ritualistic, subservient to a crude populism. News production is explained in this approach not by the public's intolerance of dissent, but by journalists imagining the public in ways that foreclose deliberation before any content reaches the citizenry.
We hope the Churchill case study promotes empirical inquiry into how "the public" is perceived by journalists during ideologically charged climates. If audiences are more tolerant than journalists imagine, we must confront the premise that journalism's self-protective instincts situate the profession as a regressive force in deliberative democracy.

\section{References}

1. Carey JW (1987) The press and public discourse. The Center Magazine 20: 4-32.

2. Goar HK (1992) Anti-intellectualism as a social control: Reflexivity and conformity. MA thesis, Mankato State University, Mankato, MN.

3. Isaacs NE (1986) Untended gates: The mismanaged press. Columbia University Press, New York.

4. Tsfati Y, Livio O (2008) Exploring journalists' perceptions of media impact. Journalism \&Mass Communication Quarterly 85: 113-130.

5. McDevitt M, Klocke B (2008) The nutty professor and the nut paragraph: News media as agent and object in the control of intellectual deviance. AEJMC.

6. McGlone MS (2005) Quoted out of context: Contextomy and its consequences. Journal of Communication 55: 330-356.

7. Churchill W (2003) On the justice of roosting chickens: Reflections on the consequences of U.S. imperial arrogance and criminality. AK Press, Oakland.

8. Tuchman G (1972) Objectivity as strategic ritual: An examination of newsmen's notions of objectivity. American Journal of Sociology 77: 666-679.
*Corresponding author: Michael McDevitt, University of Colorado, Colorado 80309-0478, USA, Tel: 303-735-0460; Fax: 303-492-0969; E-mail: mike.mcdevitt@ colorado.edu

Received December 16, 2011; Accepted December 16, 2011; Published December 18, 2011

Citation: McDevitt M (2011) Journalists' Perception of a Punitive Public: Explaining the Impulse of Social Control. J Mass Communicat Journalism 1:e101. doi:10.4172/2165-7912.1000e101

Copyright: @ 2011 McDevitt M. This is an open-access article distributed under the terms of the Creative Commons Attribution License, which permits unrestricted use, distribution, and reproduction in any medium, provided the original author and source are credited. 